\title{
THE RENDULIC RULE AND THE LAW OF AERIAL WARFARE
}

\author{
Mateusz Piątkowski
}

\section{Introduction}

Having its origins in the case law of the International Military Tribunal, the so-called Rendulic rule creates a normative standard of the 'reasonable commander' from the perspective of international criminal law. In fact, the IMT absorbed reflections originating in national criminal law regimes, which exclude criminal responsibility in the event of error in facti. The Rendulic case concerns decisions that are made by the commanders on the battlefield, based on faith in intelligence data or other facts that later transpire to be irrelevant, outdated or even false. Especially as regards aerial warfare, the level of accordance between factual knowledge prior to an air operation and the reality on the ground is essential. The aim point of this of my research paper is to show the origins of the rule and their place in the criminal law defences catalogue, whilst analysing the Rendulic rule from the perspective of aerial warfare.

* MA Department of Public International Law, Faculty of Law, University of Łódź. Master's thesis topic “The Legal Regime of Aerial Warfare”; defended in 2012. 


\section{Error in facti in domestic and international criminal law}

Generally speaking, a mistake of fact precludes criminal responsibility. This concept is described by the Latin words: ignorantia facti excusat ${ }^{1}$. In the Polish penal system, any person having acted upon the basis of an error in facti is not deemed culpable for any crimes which require specific intention ${ }^{2}$. Polish academics have highlighted the fact that an error in facti represents an inconsistency between reality and the reflection of reality in the mind of the perpetrator (mens rea in common law) ${ }^{3}$. In the common law system, such a mistake precludes the existence of the element of a guilty mind and means that no intention to commit the crime can be proved. In other words, the dissonance between the objective facts and their subjective perception exclude the intention to commit the crime. However, an unjustified mistake of fact will lead to culpability for a criminal offence whenever the law dictates that a particular crime requires negligence or recklessness (as opposed to strict intention) as the requisite mens rea. German criminal law also contains similar solutions ${ }^{4}$ and underlines the fact that the absence of awareness (of a fact) in the defendant's mind means that his behaviour fails to contain the elements of a crime ${ }^{5}$. English law recognises error in fact as a form of defence since

1 G.K. McDonald and O. Swaak-Goldman, Substantive and Procedural Aspects of International Criminal Law: The Experience of International and National Courts, Vol. 1: Commentary, Kluwer Law International, Den Haag 2000, p. 375

2 Art. 29 of Polish Penal Code, Polish OJ 1997 No. 88, item 553.

3 Prawo karne materialne. Część ogólna i szczególna (Polish Penal Law. General and Special Parts), M. Bojarski (ed.), Lexis Nexis, Warszawa 2010, p. 185 et seq.; Kodeks karny. Komentarz (Polish Penal Code. A Commentary) T. Bojarski (ed.), Lexis Nexis, Warszawa 2011 pp. 93-95; W. Wróbel, A. Zoll, Polskie prawo karne. Część ogólna (Polish Penal Law, General Part) Znak, Kraków 2010, pp. 381-387.

$4 \S 16$ (1) of the German Penal Code (StGB) in the version promulgated on 13.11.1998, German OJ, I p. 3322, as amended.

5 M.E. Badar, Mens rea - Mistake of Law \& Mistake of Fact in German Criminal Law: A Survey for International Criminal Tribunals, 'International Criminal Law Review' 2005, No. 5, p. 203, at p. 236. 
the Morgan case; the court held that reasonable or not, a mistake of fact will preclude criminal liability when the defendant honestly demonstrates the absence of the mental element ${ }^{6}$.

In international criminal law, the mistake of fact doctrine is recognized in Article 32 (I) of the International Criminal Court Statute. Some disputes arose concerning the character of mistake (reasonable, justified, honest or simply a misunderstanding which arises by virtue of a defect in the defendant's mentality) ${ }^{7}$. Most authors agreed that, in light of Article 32 of the ICC Statute, a mistake of fact occurs when an accused directs his action in an honest but mistaken awareness of the factual background which justified his behaviour, so in conclusion it negates the requirement of mens rea (mental element) from Article 30 of the ICC Statute ${ }^{8}$. Considerations about Article 32 of the ICC Statute are still in some abstract as regards the scope of their practical applicability, given the fact that no defendant has ever invoked this kind of mistake as a defence in proceedings before the ad hoc tribunals or the ICC (the Lubanga case concerned a mistake of law, as opposed to fact) ${ }^{9}$.

R. Cryer considers that, insofar as applicable to battlefield realities, Article 32 of the ICC Statute must be examined in light of the elements of command responsibility described in Article 28 of the ICC Statute, especially since recalling the error in facti doctrine implies that criminal

6 K. Doerman, Elements of War Crimes under the Rome Statute of the International Criminal Law, Cambridge University Press, Cambridge 2003, p. 493; I. Bantekas and S. Nash, International Criminal Law, $2^{\text {nd }}$ edition, Cavendish Publishing Limited, 2003, p. 141.

7 See R. Cryer, H. Friman, D. Robinson and E. Wilmhurst, An Introduction to International Criminal Law and Procedure, Cambridge University Press, Cambridge 2010, p. 414; "even unreasonable mistakes may preclude criminal culpability" (E. von Sliedregt, Individual Criminal Responsibility in International Law, Oxford University Press, New York 2012 p. 284); but see A. Cassese, G. Acquaviva, M. Fan and A. Whiting, International Criminal Law: Cases and Commentary, Oxford University Press, New York 2011, p. 500.

8 Y. Dienstein, War, Aggression and Self-Defence, Cambridge University Press, Cambridge 2011, p. 138.

9 W. Schabas, The International Criminal Court: A Commentary on the Rome Statute, Oxford University Press, New York, 2010, p. 501; Geert-Jan C.J. Knoops, Defences in Contemporary International Criminal Law, Martinus Nijhoff Publisher, Leiden 2008, p. 143; M. Królikowski, P. Wiliński and J. Izydorczyk, Podstawy prawa karnego międzynarodowego [Principles of International Criminal Law], Wolters Kluwer, Warszawa 2008, p. 195. 
liability will exist when a person 'should have known' the relevant facts ${ }^{10}$. This judgment reflects the construction known as 'wilful blindness', which does not form part of the final draft of the Rome Statute ${ }^{11}$. However, it is possible to examine the practical aspect of a commander's decisions on the battlefield when acting on the basis of a mistake of factual knowledge. Historically, such issues were invoked in the IMT case law The Hostage Trial.

\section{Rendulic Case}

General Lothar Rendulic was a commander of the German 20 $0^{\text {th }}$ Mountain Army, which was operationally responsible for the area of subpolar Norway between 1944 and 1945. Due to the withdrawal of Finland from the war, the German forces in northern Norway and Finland were in a serious danger from the anticipated Soviet offensive along the whole front. General Rendulic ordered his forces to evacuate and began destroying urban areas, dwellings and infrastructure in northern Norway (the scorched earth policy). After the war, Norway's authorities indicted general Rendulic for violating of article 23 (g) of the Fourth Hague Convention, which generally forbids the destruction of property not justified by the military situation ${ }^{12}$. In fact, Rendulic made his decision relying on intelligence data which caused alarm within the German command, given the massive preparations on the Soviet side. In January 1945 it was clear that the Red Army would never mount an assault against the Wehrmacht stations in Norway, so the Rendulic order was issued (resulting in the intentional destruction of infrastructure) with no

10 R. Cryer, supra p. 415; but see very controversial judgment in the Yamashita case, Law Reports of Trials of War Criminals, The United Nations War Crimes Commision, London 1948, p. 1-2.

11 A. Eser, Individual Criminal Responsibility Mental Elements Mistake of Fact - Mistake of Law [in:] O. Triffterer, 'Commentary on the Rome Statute of the International Criminal Court', Beck, München 2008, p. 931.

12 "To destroy or seize the enemy's property, unless such destruction or seizure be imperatively demanded by the necessities of war" Convention (IV) respecting the Laws and Customs of War on Land and its annex: Regulations concerning the Laws and Customs of War on Land. The Hague, 18.10.1907, http://www.icrc.org/ihl.nsf/full/195 
military necessity justification. The IMT examined the circumstances of the case, upon reflection, concluded that the defendant's behaviour was not criminal since it was based on an honest error in judgment of the general conditions and factors in the military situation during the final months of $1944^{13}$.

The IMT justification is lacking in details, which was underlined by N. Hayashi ${ }^{14}$. First of all, the tribunal did not widely describe the grounds for the judgment. The IMT analysed the relevant data coming from intelligence and air reconnaissance, and admits that the mixture of factors and conditions were sufficiently relevant to justify general Rendulic's decision. Secondly, the tribunal failed to prove why the scorched policy order was a reasonable response to the threat of a Soviet offensive. The IMT focused solely on the general context of the situation, without giving much consideration to what kind of data and facts were available, or would have been available, to the commander. Some valuable information was described in Rendulic's testimony, wherein the defendant explained the difficulties in obtaining proper and relevant air reconnaissance results ${ }^{15}$.

13 "These things when considered with his own military situation provided the facts, or want thereof, which furnished the basis for the defendant's decision to carry out the 'scorched earth' policy in Finmark as a precautionary measure against an attack by superior forces. It is our considered opinion that the conditions as they appeared to the defendant at the time, were sufficient upon which he could honestly conclude that urgent military necessity warranted the decision made. This being true, the defendant may have erred in the exercise of his judgment, but he was guilty of no criminal act. We find the defendant not guilty on this portion of the charge" Trial of War Criminals under the Nurmberg Military Tribunal Volume IX 'The Hostage Case' 'The High Command Case' United Nations War Crimes Commission, Washington 1950, p. 402.

14 N. Hayashi, The Role of Judges in Identifying the Status of Combatants, 'Acta Societatis Martensis' 2006 p. 86, http://www.martens.ee/acta/2/069-092_Hayashi.pdf (accessed 31.1.2013).

15 "During the decisive period of time, the middle of November, for practical purposes it was no longer possible to reconnoiter. The airbases had all been transferred to Norway. The nearest one was in Butevos, which is about 1,000 kilometers distant from the Murmansk railway. Around about that time daylight lasted only a very few hours each day. The Arctic night had already extended over the majority of the 24 hours. Therefore, at such a great distance for a flight and with the very short period of daylight, it was not possible to reconnoiter the movements along the Murmansk railway thoroughly." Hostage Case, The High Command Case, Trial of War Criminals Before The Nuremberg Military Tribunal, Vol. XI. Washington 1950, p. 1132. 
Three factors were especially significant as regards the liability of the $20^{\text {th }}$ Mountain Army commander: a) the distance, b) the weather c) and the specificity of the polar winter conditions. After having taken account of all these circumstances, the tribunal held that "the extreme cold and the short days made air reconnaissance almost impossible". Doubtless, this analysis would have played a major part in the IMT's justification of the Rendulic Case, but still the core of the judgment requires further explanation. As regards aerial warfare, the tribunal's viewpoint constitutes an important yardstick that should be taken account of in the process of decisionmaking on the battlefield, described by A.P.V. Rogers as being made in the heat of the moment ${ }^{\prime 16}$. The Rendulic rule, as recognized academically, creates the standard of a reasonable commander whose actions are judged according to the relevant data and the knowledge gained or information which was possible to collect prior to launching a military operation ${ }^{17}$. Reflections of the IMT's judgment could be seen in the multiple states reservations to Part IV of the I Additional Protocol which indirectly mentioned the essential findings of tribunal judgment ${ }^{18}$.

16 A.P.V. Rogers, Zero-casualty Warfare, 'International Review of Red Cross' 2001, No. 837.

17 Statement of David W. Glazier Professor of Law at Loyola Law School, Los Angeles, Hearing on Rise of the Drones II: Examining The Legality Of Unmanned Targeting, United States House of Representatives Committee on Oversight and Government Reform Subcommittee on National Security and Foreign Affairs 28.4.2010, http:// www.fas.org/irp/congress/2010_hr/042810glazier.pdf (accessed 31.1.2013); J.E. Talbot, Unexpected Consequences From Knock-On Effects: A Different Standard for Computer Network Operations?, 'American University International Law Review' 2003, Vol. 18, No. 5, p. 1183; "The Rendulic Rule demands examination of a particular situation as it appeared to the commander at the time of the decision" M.L. Beran, The Proportionality Balancing Test Revisited: How Counterinsurgency Changes Military Advantage, "The Army Lawyer' August 2010, p. 8; F. F Martin, S.J. Schnably, R. Wilson, J. Simon and M. Tushnet, International Human Rights and Humanitarian Law: Treaties, Cases, and Analysis, Cambridge University Press, New York 2006, p. 536; D.A.G. Lewis, The Protection of Civilian Institutions During The Active Hostilities of International Armed Conflicts in International Humanitarian Law [in:] J. Grimheden, R. Ring (eds.), 'Human Rights Law: From Dissemination to Application: Essays in Honour of Göran Melander', Martinus Nijhoff, Leiden 2006, p. 102.

18 E.g. German Federal Republic reservation from 14.2.1991: "the decision taken by the person responsible has to be judged on the basis of all information available to him at the relevant time, and not on the basis of hindsight" (available at: http://www.icrc. 


\section{Historical Aspect}

During the history of aerial warfare, the Rendulic rule could be invoked many times as part of the international criminal law defence. From the very beginning of the Second World War, this construction could be adopted in various circumstances. On the morning of 1.9.1939, the German Luftwaffe bombed a small border town in Poland, called Wielun $^{19}$. Certain authors strongly advocate that the reasons for the Ju-87 Stuka dive bombers' deadly run against the civilian population in the town were justified by intelligence reports and military activity around the area $^{20}$. In their viewpoint, the Wielun bombing represented an unfortunate mistake rather than any deliberate action of the German airmen against a provincial town and designed to spread terror. At this point, one thing is especially clear - the town was attacked at around 5 A.M and somehow it is deemed to be the first action in the Third Reich's invasion of Poland. This fact leads to an interesting conclusion. The majority of authors agree that elements of the Rendulic rule came to be applied during the process of achieving the decision amidst the duress of the battlefield, and more precisely - in the spirit of military necessity. Whilst it remains questionable whether or not the Wielun bombing constituted a crime committed during peacetime or war, the conditions

org/ihl.nsf/NORM/3F4D8706B6B7EA40C1256402003FB3C7?OpenDocument), United Kingdom declaration from 2.7.2002 "Military commanders and others responsible for planning, deciding upon, or executing attacks necessarily have to reach decisions on the basis of their assessment of the information from all sources which is reasonably available to them at the relevant time", http://www.icrc.org/ihl.nsf/NORM/0A9E03F0F2E E757CC1256402003FB6D2?OpenDocument, J Gaudreau, The reservations to the Protocols additional to the Geneva Conventions for the protection of war victims, 'International Review of the Red Cross' March 2003, No. 849, pp. 13-14.

19 See more Wieluń był pierwszy. Bombardowania lotnicze miast regionu łódzkiego we wrześniu 1939 r. (Wielun was first. The aerial bombardment of towns in the area of Lodz in September 1939), J. Wróbel (ed.), Łódź 2009; T. Olejnik, Wielun - polska Guernica (Wielun - the Polish Guernica) http://wbi.d2.pl/wtn/00/album39popr.pdf (accessed 31.1.2013).

20 G. Bębnik, Wieluń, 1 września 1939r. (Wielun $1^{\text {st }}$ September 1939) [in:] Wieluń... supra, p. 55; M. Emmerling: Luftwaffe nad Polska 1939, cz. III: Stukaflieger, (Lutfwaffe over Poland 1939, part III: Stukaflieger) Armagedon Gdynia 2007, p. 21. 
of the Luftwaffe air raid certainly lacked the necessary elements of typical combat operations. The perpetrators of this deadly action, especially the head of the German Air Force's dive bomber regiments, General Wolfram von Richthofen, planned and conducted their air attack in a military situation devoid of urgency. The operation was prepared from the last day of August 1939, when the political situation between Poland and the Reich was turbulent but still peaceful ${ }^{21}$. During the summer months of 1939, the Luftwaffe planes flew hundreds of reconnaissance missions to collect intelligence data concerning further targets, in direct violation of Polish airspace. As regards the Wielun bombing, the German Air Forces were able to easily verify the location of military targets inside and outside the urban area, based on intelligence data and the important fact that the town itself lay almost on the state border. Herman Goering explained, during his testimony at the IMT, that during the air campaign in Poland, the Luftwaffe sent photographic missions before and after the attack as a method of verifying targets ${ }^{22}$. Prior to the Wielun air strike, the $76^{\text {th }}$ Dive Bombers Regiment, which carried out the mission, deployed two Dornier Do-17 reconnaissance bombers a few minutes prior to the planned take off of the whole squadron ${ }^{23}$. Their task was to conduct a final examination of the area nearby the town and the latest movements of the Polish ground forces. As the investigations of the National Remembrance Institute show, proper reconnaissance would not have detected any military activity in Wielun ${ }^{24}$. However, the Do-17 had failed to find the town due to the dense morning fog but, nevertheless, the $76^{\text {th }}$ Dive Bombers HQ decided to arm and scramble the whole unit for the bomb raid. Such activity definitely breaches the reasonable commandeering standard described in the Rendulic judgment. The head of the action, Wolfram von Richthofen, failed to

21 On 30.8.1939, the German Air Forces High Commander, Marshall Herman Goering sent an encrypted message to field units of the Luftwaffe codename "Ostmarkflug" which meant the global air attack over Polish airspace.

22 Proceedings $8^{\text {th }}$ March - 23 ${ }^{\text {rd }}$ March 1946, Trial of War Criminals Before The Nuremberg Military Tribunal, Vol. IX. Nuremberg 1946-1949, p. 562.

23 M. Emmerling, supra, p. 20.

24 The investigation files showed that Wielun had been devoid of any military activity since 30.8.1939. Investigation S/10/04/Zn from 9.6.2011, The Institute of National Remembrance - Commission for the Prosecution of Crimes against the Polish Nation, Łódź Branch. 
acquire the whole available information and data about the target and military objects therein. It is especially incriminating that von Richthofen decided to give the green light for the dive bombers to commence action, without knowing the results of the Do-17 reconnaissance mission. Such factors and the condition of the Luftwaffe air raid against the town of Wielun justify the notion that the bombing of Wielun constituted a deliberate and an intentional action. Some authors have suggested that the character of the Do-17 missions was other than it might have been (see footnote below) ${ }^{25}$. In such case, the Rendulic rule as a standard of reasonable commander will be inapplicable, which indicates the criminal liability of those commanding the action.

\subsection{The Chinese Embassy Bombing in Belgrade, 1999}

At midnight on 7.5.1999, during the NATO operation Allied Shield, two B-2 bombers of the United States Air Forces hit the building of the Chinese Embassy in Belgrade, the capital of the Federal Republic of Yugoslavia (FRY ${ }^{26}$. As a result, three people were killed, and a dozen more were injured. The political, diplomatic and military background and worldwide discussion following the attack created a very sensitive issue in international relations between China and NATO countries ${ }^{27}$. The bombing represents an example of a clear error, the primary target of the action being the building of the Federal Directorate for Supply and Procurement in Belgrade whose location was mistaken in intelligence

25 S. Abramowicz suggests, that the primary objective of the two Do- 17 bombers was to examine the area of Wielun and to confirm that it did not possess any anti-aircraft battlements. S. Abramowicz, Tragedia Wielunia w świetle materiałów śledztwa Oddziałowej Komisji Ścigania Zbrodni przeciwko Narodowi Polskiemu (Tragedy of Wielun in the light of Investigation Files of the Commission for the Prosecution of Crimes against the Polish Nation, Lodz Branch) [in:] Wieluń..., supra.

26 BBC World 8.5.1999, Nato hits Chinese Embassy http://news.bbc.co.uk/2/hi/ europe/338424.stm (accessed 31.1.2013)

27 See Security Council Debate Concerning Letter Dated 7.5.1999 from the Permanent Representative of China addressed to the President of the Security Council (S/1999/523), S/PV, 4000, 8.5.1999 [in:] H. Krieger, 'The Kosovo Conflict and International Law: An Analytical Documentation 1974-1999', Cambridge University Press, Cambridge 2001, para. 254, p. 440; United Nations Press Release SC/6674/Rev.1 http://www.un.org/News/ Press/docs/1999/19990508.SC6674.R1.html (accessed 13.1.2013). 
reports during the planning phase of the attack. In the conclusion of that process, NATO intentionally targeted the embassy, albeit on the basis of false data which it possessed at the moment of planning the strike. The application of the Rendulic rule in this situation requires further commentary. First of all, one should remember the difference between an error and an accident. When conducting an air operation, an attacking plane could lock onto the correct, legitimate target but the fired missile may accidentally actually strike the wrong object (civilian), for example due to a technical failure ${ }^{28}$. In such circumstances, it is impossible to determine the existence of a justified mistake made by the air force staff at different stages. The situation described above has frequently occurred in the history of aerial warfare, when the fault of armament, the target instruments or unpredictable weather create situations which are generally beyond the control of the operators ${ }^{29}$. Such circumstances do not give rise to criminal responsibility. In the case of the Chinese Embassy bombing, the US bombers located, tracked and locked a target properly and used their weapons against the selected target which had been incorrectly identified as a military object. Action was taken intentionally against the FRY military facility, but the result was that a non-legitimate target was bombed because of an incorrect targeting system, inaccurate maps and the lack of precautions during the planning process ${ }^{30}$. As regards the Rendulic rule, the standard of the reasonable commander was not met by NATO operational control, especially since such mistakes should have been detected and reviewed during a proper verification phase. The majority of authors agree that NATO failed to do everything feasible in the scope

28 Moreover, it also could be understood as the result of using types of weapons which do not guarantee the maximum possible accuracy and cause collateral damage, such as field artillery. For further details, see the discussion over 200 meter standard created by the ICTY in the Gotovina case (Gotovina, Case No. IT-06-90-T, Judgment, para. 1898; W.B. Huffman, Margin of Error: Pitfalls of the Ruling in The Prosecutor v. Ante Gotovina, 'Military Law Review' 2012, Vol. 211).

29 See the circumstances of the bombing of a hospital in Bach Mai, Hanoi, during the Linebacker offensive over North Vietnam in 1972 (W.H. Parks, Linebacker and the Law of War, 'Air University Review' 1983) and the case of the Nis hospital attack in 1999.

30 Final Report to the Prosecutor by the Committee Established to Review the NATO Bombing Campaign Against the Federal Republic of Yugoslavia, paras 81-82, http://www. icty.org/sid/10052\#IVB4 (accessed 31.1.2013). 
of the requirements laid down in article 57 (2) of the First Additional Protocol, especially as regards taking possible precautions during the planning phase of the 7.5.1999 air raid ${ }^{31}$. Amnesty International's report stated that (...) the very basic information needed to prevent this mistake was publicly and widely available at the time ${ }^{32}$. The level of misconduct involved in the decisions and actions taken by NATO, and its failure to properly identify the Embassy building, could be examined in the light of their evident recklessness ${ }^{33}$. Pursuant to the Rendulic rule, NATO definitely should have verified its intelligence data, particularly given that its air operations were planned in an urban area, where the consequences of mistake are significantly harmful to the civilian population. During such aerial activity, a commander's level of precautions could be described as including the duty to undertake extensive preparations to avoid any possible risk and to minimalize or eradicate any margin of error. Since the US officially apologized for the action and paid compensation to the victims and their families, no international criminal proceedings were initiated ${ }^{34}$. The case of the Chinese Embassy bombing represents a culpable mistake of NATO intelligence and its planning process, but it cannot be considered as intentional, since the mistake of fact, even if unreasonable, does not amount to the same as having the intent to commit a crime. In light of the Rendulic judgment, the USAF definitely had to review their planning process, since most errors were created by the absence of supervisory control.

31 T. Voon, Pointing the Finger: Civilian Casualties of NATO Bombing in the Kosovo Conflict, 'American University International Law Review' 2001, No. 4, p. 1110.

32 Amnesty International, NATO/Federal Republic of Yugoslavia "Collateral Damage” Or Unlawful Killings? Violations of the Laws of War by NATO during Operation Allied Force. D. Tian reviewing the official U.S apology noted that "the United States and NATO were able to detect the complicated mistakes that led to the bombing of an embassy within several "intervening hours." (D. Tian, U.S. and NATO Apologies for the Chinese Embassy Bombing: A Categorical Analysis, 'International Journal of Communication' 2007, Vol. 1, p. 371).

33 W.J. Fenrick described it as "advanced intelligence errors" (W.J. Fenrick, Targeting and Proportionality during the NATO Bombing Campaign against Yugoslavia, 'European Journal of International Law' 2001, Vol. 12, p. 499; B.S. Lambeth, Nato's Air War for Kosovo: A Strategic and Operational Assessment, 'Rand Santa Monica' 2001, pp. 145-146).

34 The Final Report... supra, paras. 84-85. 


\subsection{Al-Firdos shelter bombing, Gulf War 1991}

During the first war in the Gulf in 1999, the United States Air Forces (USAF) and supporting Allies conducted a massive air campaign against Iraq. During the first phase of those air strikes, on the night of 13.2.1991, two F-117 destroyed the Al-Firdos shelter in Bagdad ${ }^{35}$. As a result, at least 200 civilians were killed. The death toll was exceptionally high because the bunker had been converted into a civilian shelter and was being used as shelter during the Coalition air raids. USAF hit the bunker deliberately and intentionally, considering that it was a command centre - a lawful target within the meaning of the First Additional Protocol and the customary rules governing aerial warfare ${ }^{36}$. Humans Rights Watch blamed the U.S military having failed to take all available precautionary measures and for having failed to issue a warning of the type described in article 57 of the First Additional Protocol. Ultimately, the USAF must have known about the civilian character of the Al-Firdos bunker, since flight reconnaissance mission would have been sent in the morning of 13.2.1991 ${ }^{37}$. In response, the U.S military revealed the reasons for the F-117 night bomb raid: the building was constructed during the late 80 's by a Scandinavian contractor who testified that the bunker was intended to play a military role in a forthcoming air campaign ${ }^{38}$. Secondly, it was camouflaged (which is inconsistent with the requirements for civilian shelters laid down in article 66 (2) of the First Additional Protocol) and intelligence had

35 R.D. Rosen, Targeting Enemy Forces in the War on Terror: Preserving Civilian Immunity, 'Vanderbilt Journal of Transnational Law' 2009, Vol. 42, No. 3, p. 752-753; M. Sławiński, Collateral Damage in Air Operations, 'Zeszyty Naukowe Akademii Podlaskiej w Siedlcach' 2010, No. 86, p. 181; Conduct of Persian Gulf War, Final Report to Congress, Chapter VI http://www.ndu.edu/library/epubs/cpgw.pdf (accessed 31.1.2013).

36 M.C. Waxman, Detention As Targeting: Standards of Certainty and Detention of Suspected Terrorists, 'Columbia Law Review' 2008, Vol. 108, p. 1390.

37 “The need for such disclosure is particularly important in view of the U.S. military's acknowledgment that the building originally served as a civilian shelter during the IranIraq war and its contention that the building only recently "became" an active commandand-control bunker", Needless Death in Iraq, Chapter 3, Human Rights Watch http://www. hrw.org/reports/1991/gulfwar/CHAP3.html (accessed 31.1.2013).

38 M.W. Lewis, The Law of Aerial Bombardment in The 1991 Gulf War, 'American Journal of International Law' 2003, Vol. 97, p. 503. 
detected intense radio communications emanating from the site, such as are characteristic for control and centre command ${ }^{39}$. All such findings were confirmed by military vehicle traffic and satellite coverage.

In view of international humanitarian law, the USAF intentionally hit the Al-Firdos bunker, considering it to be a military object within the meaning of the First Additional Protocol. Such a configuration of facts requires the application of the Rendulic rule and a close examination of the circumstances of the F-117 air raid in light of the reasonable commander standard. Having considered the intelligence data and other sources of knowledge, the Al-Firdos bunker attack seems to be justified in light of the relevant information available to the USAF command at the time, and academics agree that this conduct does not amount to a violation of the ius in bello rules and customs ${ }^{40}$. The process of collecting target information seemed to be honest and complete. The radio monitoring, photo reconnaissance, satellite coverage and intelligence data had confirmed the military character of $\mathrm{Al}$ - Firdos shelter.

\section{Commentary}

The IMT findings relating to the Rendulic judgment constitute an important direction in the judicial interpretation of facts and data available to a commander at the relevant time. In the case of WWII

39 S.C. Tucker, The Encyclopedia of Middle East Wars: The United States in the Persian Gulf, Afghanistan, and Iraq Conflicts, Vol. 1, ABC - Clio, Santa Barbara 2010, p. 97.

40 "Assuming the decision to bomb the shelter was reasonable in light of the intelligence available at the time, no violation of the law of war occurred" (A.L. DeSaussure, The Role of the Law of Armed Conflict During The Persian Gulf War: An Overview, 'Air Force Law Review' 1994, Vol. 37, p. 65; "The military's conclusion that this was a legitimate target was not incorrect" (W. Lewis, The Law of Aerial... supra, p. 504); "Although the Al-Firdos incident was an accident, not a violation of the laws of war (...)" (R. Grant, In Search of Lawful Targets, 'Air Force Magazine', February 2003, p. 42); “(...) Al-Firdos command and control seemed a justifiable military target (...)” (P.G. Gillespie, Weapons of Choice: The Development of Precision Guided Munitions, University of Alabama Press, Tuscaloosa 2006, p. 156); "The bombing of the Al Firdos bunker was not a war crime" (G.D. Solis, The Law of Armed Conflict: International Humanitarian Law in War, Cambridge University Press, New York 2010, p. 258; (...) there could be no war crime because of a lack of intent" (A.P.V. Rogers, Law on the battlefield, Juris Publishing, Manchester 2006, p. 75). 
air operations, the manner of judging instances of aerial bombardment was based predominantly on a post factum perspective, when the facts were revealed following the combat actions. In many cases, this led to some very unjustified conclusions. While the Rendulic standard could be examined from two different aspects, the IMT considerations mostly review the issue of a commander's good faith, as opposed to the possibility of receiving the required knowledge of the target area. The wanton destruction of Norwegian sub-polar territory was based on the sufficient ground (in the IMT's view) of an objective inability to acquire a proper intelligence report of the anticipated Soviet offensive. The scorched earth order issued by general Rendulic was a reasonable decision, which would have been taken by a majority of commanders in such conditions ${ }^{41}$. The Tribunal superficially examined the possibilities of the German side acquiring data from air reconnaissance or intelligence activity, based mostly on the severe weather explanation. The history of air raids in the Second World War demonstrates that, most frequently, the element of good faith was patently lacking during the intentional bombardment of cities and towns. The possible applicability of the Rendulic rule was limited only to situations where the perpetrators tried to exculpate their actions by targeting objects which appeared to be lawful military targets. While the Hague Conventions merely require that defended and undefended locations be distinguish, the criterion of a military target was still not recognized in international practise ${ }^{42}$. During the IMT trials, the

41 Similar interesting argumentation was raised in the trial of Admiral Karl Doenitz. Doenitz was accused of violating the rules governing unrestricted submarine warfare, which were non-applicable in battlefield practise. The Admiral's legal counsels argued that both sides in the WWII conflict refused to fulfil the London Treaty requirements and that contrary orders and instructions were issued by the Royal Navy and United States Navy. The defence line positions ground on the impracticability of the Treaty provisions which contradicted justifiable military logic. See more: Office of the United States Chief of Counsel for Prosecution of Axis Criminality, Nazi Conspiracy and Aggression, Opinion and Judgement, United States Government Printing Office, Washington 1947, p. 137 et seq.

42 "The attack or bombardment, by whatever means, of towns, villages, dwellings, or buildings which are undefended is prohibited" (article 25 of the Convention (IV) respecting the Laws and Customs of War on Land and its annex: Regulations concerning the Laws and Customs of War on Land. The Hague, 18.10 .1907 (full text: http://www. icrc.org/ihl.nsf/full/195). The Hague Rules of Aerial Warfare from 1923 were a first attempt to establish a first international regulation dedicated only to the air combat 
Prosecutor decided not to indict the High Commander of the Luftwaffe, Herman Goering (and other defendants) for being responsible for German Air Force actions against Wielun, Warsaw, Rotterdam, London, Coventry and Belgrade, despite the fact that these bombings constituted grave violations of customary international law ${ }^{43}$. Further discussion was dismissed by the Tribunal's standpoint in the Einzatzgruppe Case, which recognized an Allied bombing campaign against German cities as an act of legitimate warfare ${ }^{44}$. In such conditions, when the legal value of rules covering aerial operations remained questionable, there was no space for the Rendulic rule to be applied. Some issues were raised only as a result of the development of international humanitarian law ${ }^{45}$. During postWWII conflicts, the significance of aircraft on the modern battlefield has dramatically risen. Equally, the standards of legal conduct have increased, seeking to close loopholes in the ius in bello regulations concerning aerial warfare (e.g the First Additional Protocol). Furthermore, international

operations, including aerial bombardment. Despite the fact that this provision was not binding during the World War Two, it has been argued that article 25 of the IV Hague Conventions from 1907 is applicable by analogy to the aerial warfare issue (see more: R. Wymann, The First Rules Of Air Warfare, 'Air University Review' 1984).

43 During the Nuremberg Trials, the issue of aerial bombardment was raised in testimony during the trial of Albert Kesserling, a chief commander of the Luftflotte (Air Fleet) responsible for attacking Warsaw during September 1939. Kesserling described the indiscriminate bombing of the Polish capital city as a lawful air action against a fortified city falling within the scope of art. 25 of the IV Hague Convention (Proceedings 8 March 23 March 1946, Trial of War Criminals Before The Nuremberg Military Tribunal, Vol. IX, International Military Tribunal, Nuremberg 1949, p. 176). While statutory international humanitarian law did not provide a regulation dedicated to aerial warfare, nevertheless, grounds existed for recalling customary international law insofar as providing civilian immunity from terror air actions. See footnote below for further explanation.

44 The case of the Allied Strategic Bomber Offensive was a sensitive matter, especially when the war criminals demands to be judged by the same standards as Allied commanders who directed the massive air operations over Germany during WWII. "Reasons of fairness and justice demand that Field Marshal List be treated in this respect exactly as were those Allied commanders who gave the orders to attack Dresden and Hiroshima" (Einsatzgruppe Case, Trial of War Criminals Before The Nuremberg Military Tribunal, Vol. IV. Nuremberg 1946-1949, Washington 1950, p. 466-467). IMT avoids an awkward discussion by rejecting the defendants' demands, considering them to be disproportionate and incomparable to the scale of Nazi regimes crimes.

45 See Shimoda et al. v. The State, Tokyo District Court, 7.12.1963, 'Hanrei Jiho', Vol. 355, p. 17; translated in 'Japanese Annual Review of International Law' 1964, Vol. 8, p. 231. 
organizations have imposed upon themselves a new level of conducting combat operations, based primarily on the inviolability of civilian populations and the rapid technology advancement in weaponry and targeting instruments ${ }^{46}$. However, as pointed by W.B Huffman against the background of the Gotovina judgment, even the most accurate bombing technique will not guarantee that the collateral damage effect can be confined to past decades ${ }^{47}$. Civilian casualties will remain an inseparable part of combat operations, especially when fought in urban conditions. Commanders are required to act in such circumstances in good faith and in accordance with the provisions of international humanitarian law. At the time of the decision-making process, it is necessary to take feasible measures to properly recognize a target as a lawful military object and to evaluate the proportionality and humanity principles. During that phase, even the most accurate intelligence efforts could be erroneous or in conflict with the real situation pertaining at the moment of an air attack (e.g in case of Al-Firdos shelter bombing). The level of fairness planning and the existence of bona fide at the relevant time should be examined against the reasonable commander standard, which is the core of the Rendulic rule. The IMT's findings allowed international criminal law to introduce a construction which could be considered as a directive forbidding a commander's decisions to be assessed in the light of post factum data and facts.

\section{Conclusion}

The concept of the Rendulic rule, revealed by the IMT during the Nuremberg trials, has been considered to constitute a reflection of similar

46 See "zero casualty standard” in A.P.V. Rogers, Zero-casualty warfare, 'International Review of the Red Cross' 2000, No. 837 and NATO declarations during operation Unified Protector over Libya in 2011: "NATO told the Commission that it had a standard of "zero expectation" of death or injury to civilians" (Report of the International Commission of Inquiry on Libya, United Nations Human Rights Council, 2.3.2012, p. 16, para. 84; (http://www.ohchr.org/Documents/HRBodies/HRCouncil/RegularSession/Session19/A. HRC.19.68.pdf, accessed 16.2.2013).

47 "Advanced technology has not eliminated (and cannot, for the foreseeable future, eliminate) civilian casualties from warfare" W.B. Huffman, supra, p. 21. 
solutions found in national criminal systems, especially the construction of a mistake of fact. In the history of wars during the XX century, commanders were generally judged on the facts as known from a post factum perspective. The Rendulic rule requires an assessment of battlefield actions to be undertaken in the light of the relevant information available at the time of making the decision. The practice of aerial warfare demonstrates some examples of when the Rendulic rule was applied and sometimes makes a considerable impact of an assessment of criminal culpability. Nowadays, the above-mentioned construction could be understood as an important yardstick for delimiting the proper standards of precautionary measures in the scope of the requirements laid down in the First Additional Protocol. 